\title{
Discursive Strategies in Selected Political Campaign Songs in Southwestern Nigeria
}

\author{
Ayo Osisanwo \\ Department of English, Faculty of Arts, University of Ibadan, Ibadan, Nigeria \\ Email address: \\ ayosisdelexus@yahoo.com

\section{To cite this article:} \\ Ayo Osisanwo. Discursive Strategies in Selected Political Campaign Songs in Southwestern Nigeria. Communication and Linguistics \\ Studies. Vol. 6, No. 4, 2020, pp. 73-81. doi: 10.11648/j.cls.20200604.12
}

Received: November 26, 2020; Accepted: December 8, 2020; Published: December 22, 2020

\begin{abstract}
Discursive strategies are often deployed to create awareness, capture and persuade electorate in political campaign songs. Existing scholarly works on political and electoral issues have examined different aspects of political discourses but have not sufficiently examined the import of political campaign songs in electoral and political discourses. Therefore, this paper examines the use of political campaign songs in southwestern Nigeria with a view to identifying the discursive strategies deployed to persuade the electorate. The YouTube Channel was visited in order to retrieve the transcript of political campaign jingles used during the 2011, 2015 and 2019 general elections in southwestern Nigeria. The selected period comprised the most recent general elections in the region. Guided by relevant aspects of the socio-cognitive model of critical discourse analysis, data were subjected to discourse analysis. The analysis uncovers the vital relationship existing between the political campaign songs and the Nigerian socio-cultural spatial setting that produced them. Eight discursive strategies: allusion (historical, religious/biblical, socio-cultural), propaganda, indigenous/native language usage and code alternation, reference to collective ownership, figurative/proverbial expressions, adaptation of common musical tune, and rhythmicity were identified. Politicians use different discursive and rhetorical strategies in their political campaign songs to open the door to the heart of the electorate.
\end{abstract}

Keywords: Discursive Strategies, Discourse Analysis, Political Campaign Songs, Southwestern Nigeria

\section{Introduction: Language and Politics}

The import of language (choices) in political campaign cannot be overemphasized. One of the most comprehensive definitions of language is the view that it is "human vocal noise or the arbitrary graphic representation of this noise, used systematically and conventionally by members of a speech community for purposes of communication" [1]. On the last aspect of that definition, "for the purposes of communication," how does one get communicated to? Man as a social animal constantly finds himself in an environment where there is a need for communication; hence language the main channel through which the patterns of living are transmitted from man to man [2] is mainly used to achieve this indispensable objective which distinguishes man from other animals. Language holds "the key to the heart of the people, if you lose it, you lose the people; if you keep it safe, it unlocks the people's heart" [3, 4]. This is a paramount key in the political arena. How do politicians get access to the heart of the people? Language usage in political arena constitutes a very crucial aspect of political practices speeches, jingles, campaign songs [5]. Beyond the character of the politician seeking political office, language choice plays vital roles in determining the success or failure of such aspiring political office holders at the polls.

Linguistic and discourse choices are made to gain access to the heart of the electorate in order to woo and win them over to the side of an intending public office holder. Such choices are often carefully made in the rhetoric of the speeches delivered before elections. Campaign messages and songs are crafted and sung via different media and at political party rallies, inscriptions are made on bill boards, flyers and souvenirs, and so forth, since it is a form of advertisement where the intending political contestant is properly packaged like a commodity, advertised and sold for the purchase of the electorate. When convinced, the electorate buy into their programmes and plans for the community of interest. Having settled the crafting of the commodity, the products are often made available on social and traditional media. Since advertising is a strategy used in calling the attention of the 
public to a particular product or service with the aim of inducing them to patronise the commodity, political campaign strategists can be seen as advertisers. Such strategists deploy the techniques and practices used in bringing products, services and even opinions to public notice such that the public can react in a certain way to the commodity. The different media of advertising the commodity therefore range from mouth-to-mouth advertisement to other outlets, including rallies, television, radio, billboards, internet, poster, handbills, catalogues, magazines, newspapers, and so forth [6]. Hence, all over the world today, the role of the media in political campaign cannot be overemphasized. The mass media (which may include television, radio, flyers, posters, text messages, billboards, handbills, internet among others) play a vital role in mediating between politics and the public.

The argument in this paper is that Nigerian politicians deploy different discursive and rhetorical strategies in their political campaign songs in order to open the door to the heart of the electorate. Such political campaign songs, often laden with different discursive and convincing strategies, are relayed as jingles on the radio and television, and most especially at campaign rallies to promote their good and present their opponents as bad or evil, to the public. During political campaigns, candidates often deploy different rhetorical and discursive strategies in campaign songs in order to win, to be in control or in power. Hence, politics, which in the words of Chilton [7], has been defined as 'a struggle for power, between those who seek to assert and maintain their power and those who resist it," has to do with "issues as power, legitimization, persuasion, struggles for dominance, and coercion" [8]. The thirst to be in control of power probably explains why there seems to be a lot of contest or struggle between political opponents [9]. Our concern in this study is the use of political songs during rallies. Campaign songs are often transmitted beyond the immediate spatial setting of the campaign to remote setting through the media, especially radio, television and the social media. The social media, therefore, give politicians and political contenders the opportunity to transmit their campaign messages beyond space and time.

The political scenery in Nigeria has enjoyed linguistic scholarly attention. Discourse analysts, and other linguists have given some attention to the examination of discourses on politics in Nigeria. Existing discourses have engaged, among others, advertisement and campaign discourses among Nigerian political parties $[10,11,8]$, political interviews and debates [12], political speeches of past leaders [13-15]; discourses in political campaign text messages [5] discourses in political campaign posters $[9,6]$ electoral discourses in the media [16-21], neglecting the consideration of political jingles. Most of them did not dwell on political songs and or jingles. Some of those closely related to the impact of music in politics have been carried out in other climes but Nigeria $[22,23]$ and so forth. Some of the existing ones in Nigeria include [24, 25], which did not consider the campaign songs from discourse analytic angle. Therefore, how sufficient are they? Despite the different foci of the exiting studies on politics and elections in Nigeria, a dearth of work exists on political campaign songs, especially considering the use of songs among political rivals. This paper is motivated by the insufficiency in the engagement of political discourses in Nigeria; therefore, it examines and identifies the discursive strategies deployed among politicians in convincing the electorate about their political agenda.

\section{Music and Political Campaign}

Music is one of the most rhetoric-laden media for persuasive and dissuasive intent. Music is both a powerful communication medium that expresses human actions and reactions, and a medium that reflects society to allow its members better comprehend more about life [26]. Allen [27] avers that "so many people articulate their ideas, beliefs, and feelings through its creation, performance, or consumption." Though a song is made up of both the lyrics and the music, the lyrics (which receive critical attention [28] more than any other aspect of a song) are often properly crafted to convey the intention of persuading listeners into an action or dissuading them from an action, or just giving information. Music works with other expressive cultural practices such as dance and festivals, and remains an important way that people live out their collective identities as they create and sustain social groups [29]. Hence, music has been accorded significant roles in different contexts, including religious, cultural, social and political. Music, which is capable of bringing people from various backgrounds together and creating for them a collective experience [30], can possess "a greater unifying power than other forms of campaigning because it has the ability to transcend language, cultural and socioeconomic barriers" [22]. Music significantly impacts humans at both the emotional and cognitive levels. It has continued to grow, transcending an array of possible barriers, and constituting the space where expression meets with art. Sellnow and Sellnow [31] argue that "music symbolises emotion through rhythmic patterns of intensity and release."

Music has increasingly been used in the electoral process to deliver messages about political parties, their candidates and manifestoes, and to attract potential voters in Nigeria, Africa and the world over. History has it that the 1800 election in the US has been attested to have marked the first time campaign songs were used, although how they were incorporated was significantly different from what operates today. During the earliest use of campaign songs, partisan ditties were used in American political canvasses and more especially in presidential contests. Therefore, politicians continue to seek to appropriate popular music to communicate with constituents that they may assume to be hard to reach [32]. The power of music has been attested to be multifarious in society, and its attributes make it particularly potent for political communication. The attributes include being "complexly structured, affectively significant, attentionally entraining, and immediately-yet indeterminately-meaningful" [33]. 


\section{Election in Nigeria}

Elections are conducted in Nigeria, using party system; and Nigeria operates a multi-party system, usually with two or three dominant parties. The People's Democratic Party (PDP), which dominated the current political dispensation in Nigeria for 16 years, won every presidential election between 1999 and 2011, and was in power from 1999 - 2015. The PDP's major challenger in 1999 was the All People's Party/ All Nigerian People's Party (APP/ANPP). Chief Olusegun Obasanjo (OBJ) of PDP won the election with $62.8 \%$ votes. OBJ of PDP repeated the feat with $61.9 \%$ votes in 2003 after contesting with more political parties. Upon the completion of OBJ's tenure, Umaru Musa Yar'Adua of PDP won other contestants, including General Muhammadu Buhari of Congress for Progressives Change (CPC) with $54.5 \%$ of the total votes at the general presidential elections. In the 2011 presidential election, Dr Goodluck Ebele Jonathan (GEJ) of PDP defeated all the other major contestants like Muhammadu Buhari of CPC, Mallam Nuhu Ribadu of Action Congress of Nigeria (ACN).

A new party evolved on February 6, 2013 and marked a turning point for the current democracy in Nigeria. The new party was made up of members of other parties who had conceded to having a merger in order to put to an end the sixteen years of playing the second fiddle to PDP. Hence, politicians from ACN, CPC, ANPP, a faction of All Progressives Grand Alliance (APGA), and another faction of PDP, called nPDP, came together for a merger in anticipation of the 2015 general elections. The new party was named All Progressives Congress (APC), and elected General Muhammadu Buhari (Rtd.) as the party's flag-bearer. Meanwhile on the part of the PDP, after the completion of the first term of GEJ in office, GEJ was fielded to contest the 2015 election. However, General Muhammadu Buhari (Rtd.) won GEJ in the keenly contested election with 2.4 million votes. By 2019, Alhaji Abubakar Atiku (Atiku) had deflected from the APC to the PDP. He won the primaries of the PDP and ran against the incumbent President Muhammadu Buhari (PMB). However, Atiku lost to PMB at the polls.

No doubt, cross-carpeting is a regular feature in Nigerian politics. It comes with so much ease in the Nigerian political landscape that the political parties in Nigeria had been criticised for lacking strong ideological orientation, claiming that must have accounted for the ease with which members change parties. As party members move from one party to the other, they are able to see one another's secret and the desperation to take something meaningful out of their new party must also have influenced the changing tactics in political campaign rally songs witnessed today. In an attempt to win at all costs, politicians and their political parties have often embed their political campaign songs (PCSs) with different discursive strategies aimed at arresting the attention and influencing the electorate. This study therefore examines the rhetoric deployed in some of the PCSs in order to identify the discursive strategies used in the music to convince the electorate.

\section{Theory and Method}

The present study is guided by aspects of van Dijk's [34] socio-cognitive model of critical discourse analysis (CDA). Out of the hundreds of possible categories, van Dijk (2006) introduces 27 categories of ideological discourse structures which include the following: 'actor description', 'authority', 'burden' ('Topos'), 'categorisation', 'comparison, 'consensus', 'counterfactuals', 'disclaimer', 'euphemism', 'evidentiality', 'example'/'illustration', 'generalisation', 'hyperbole', 'implication', 'irony', 'lexicalisation', 'metaphor', 'selfglorification', 'norm expression', 'number game', 'polarisation', 'Us-Them', 'populism', 'presupposition', 'vagueness', 'victimisation, dramatisation and polarisation. According to van Dijk the ideological discourse often features the following overall strategies of what might be called the ideological square: emphasise our good things, emphasise their bad things, de-emphasise our bad things, de-emphasise their good things. This theory and the structures guide the analysis in this paper. Meanwhile, we have found twenty-two of the twenty-seven useful for the purpose of this paper. They include Actor description, which has to do with the way actors or members of a particular society are described either in a negative or positive way; Authority, which has to do with mentioning authorities to support one's case; Categorisation, which has to do with the organisation of people into different groups; Comparison, which has to do with comparing ingroups and outgroups; Consensus, which has to do with a political strategy involved in forming agreement and solidarity; Counterfactuals, which is used to present imagined outcome; Disclaimers, which is used to save face by mentioning our positive characteristics but focus exclusively on their negative attributes; Euphemism which is used in avoiding negative impression formation; Evidentiality, which involves the use of some evidence or proof to support one's knowledge or opinion; Example/Illustration, which involves using concrete examples in form of short stories to illustrate or make a general point more credible; Hyperbole which is a semantic rhetorical device used for enhancing meaning; Implication, which involves deducing or inferring implicit information; Irony which is used to derogate the other - saying something and meaning something else; Metaphor which involves using imaginative and powerful words and expressions to describe; National Self-Glorification which is a device to create positive self-presentation by glorifying one's country; Negative otherpresentation, which involves classifying outgroups as bad; Norm expression, which involves giving norm statement about what "we" should and should not do; Number game, which involves using numbers and statistics to appear credible; Presupposition which is the common shared knowledge between people or the ideas taken for granted in a proposition; Polarisation, which involves categorising people as belonging to us with good attributes and them with bad attributes; Positive self-presentation, which involves classifying ingroups as good; and Dramatisation and Polarisation, which involve telling bad stories about people who do not belong to US.

The YouTube Online Channel was accessed in order to 
retrieve the transcript of political jingles used in the southwestern region of Nigeria during the 2011, 2015 and 2019 general elections in Nigeria. The selected period comprised the most recent general elections in the region. Out of the over seventy campaign songs that were retrieved, only the eleven that are illustrative of the discursive strategies were presented due to economy of space. Guided by aspects of socio-cognitive model of critical discourse analysis, data were subjected to discourse analysis in order to identify the discursive strategies deployed in the PCSs.

\section{Analysis and Discussion}

Eight discursive strategies deployed in the PCSs were identified. The eight discursive strategies are allusion (historical, religious, socio-cultural), propaganda, indigenous/native language usage and code alternation, reference to collective ownership, figurative/proverbial expressions, adaptation of common musical tune, and rhythmicity.

\subsection{Allusion (Historical, Religious, Socio-cultural)}

Allusion is the introduction of a subject into an ongoing discourse. As an important discursive strategy, politicians often deploy allusion in their political campaign songs in order to persuade the electorate, appealing to their sentiments and striving to convince them on the need to support and vote in favour of their political ambition. Three types of allusion: historical, religious, and socio-cultural are identified in our data. We will examine them in turns.

\subsubsection{Historical Allusion}

This simply has to do with reference to history. History involves previous experiences and events, whether good or bad. The mentioned historical allusion "on the experience, achievements and track records of the aspirants help the electorate to form opinions about them" [5]. Different political contestants deploy the use of history as a discursive strategy and a tool to prick or satisfy the curiosity of the electorate, by taking recourse to flashbacks of successes or failures in order to convince the addressees. To achieve historical allusion in our data, other ideological discourse structures (IDSs) such as Evidentiality, Authority, Author Description, Illustration, among others are deployed. In the PCSs, political contestants (PCs) appeal to the electorate by historically alluding to the successes already made in the past while they condemn the previous failures of their political opponents (POs) in order to build the world of the electorate against those of their POs.

$\begin{array}{lll} & \text { Fásọlá gan-gan } & \\ & \text { l'àseyọrí } & \text { Fásọlá is a symbol of } \\ \text { Text } 1 & \begin{array}{l}\text { Fásọlá gan-gan } \\ \text { l'àseyọrí }\end{array} & \text { success. } \\ & \text { Fásọlá ti sà'seyọrí } & \text { Fásọlá has succeeded in } \\ \text { E wo ìlú Èkó, ìlú Èkó } & \text { turning Lagos around. }\end{array}$

Text 1 is a sample drawn from the 2015 and 2019 presidential and gubernatorial election campaigns in Lagos.
The connotation in the expression, Fásolá gan-gan l'àseyorí (Fásolá is a symbol of success) is that Fasola is success personified. Meanwhile the second expression Fásolá $t i$ sà seyorí (Fásọlá has succeeded) explicates the fact that Fasola was able to paddle the canoe of the city of Lagos to successseashore. Babatunde Raji Fasola (BRF) was the governor of Lagos State from 2007-2015. The accolades being showered on BRF by the musician is politically motivated. The PC through the musician uses Babatunde Raji Fasola (BRF) whom history has it that he turned Lagos around, especially in terms of infrastructural development, extension of roads and others. Hence, the rhetoric in the PCS involves the deployment of IDSs like Actor description, Illustration, Implication and Evidentiality to underscore the authenticity in the claim that APC and its political representatives are success-personified, through the illustration of the personality of BRF, an APC member. The implication in the illustration suffices as evidence and historically alludes to what the party, APC, and his political members are capable of doing when voted to power. Hence, the onus lies on the electorate to embrace the candidate and party being supported by the success-personified BRF. In other words, this symbol of success can only support another achiever like him. Therefore, the electorate should embrace the same candidates and party with their vote.

\subsubsection{Religious Allusion}

This simply has to do with reference to religion; hence, religious allusion has to do with language choices which reflect certain religious affiliations. Religious allusion has recently become a common phenomenon among politicians where such PCs deliberately allude to religious beliefs in order to open the electorate's hearts or appear pious to them. In Nigerian political rallies, some politicians even allude to three different religious affiliations within a single speech in order to cater for the demands of all the three most practiced religions in Nigeria and to appeal to their sentiments, using words like Jesus (Christianity), Allah (Islam) and Ogun (Traditional). Meanwhile, in other situations, politicians navigate towards the expectations of a given audience. The examples below demonstrate the use of religious allusion in the PCSs:

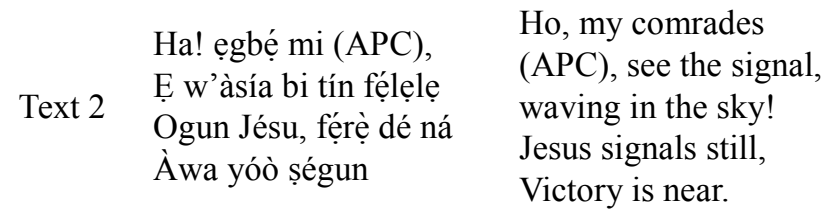

Text 2 was one of the songs rendered at different rally points in the 2015 and 2019 election campaigns. The APC sang the song as a form of attack against the PDP; the APC was putting its entire arsenal to task to ensure a people-receptive representation. The name "Jesus" used thus: Ogun Jésu, fẹrè dé ná (Jesus' angels are almost here) alludes to the Christian religion, in order for the PCs to correlate their party and contestants with the character of Jesus, who is believed to be pious. The rendition also associates the party with promised absolute success at the poll, using the IDSs of Counterfactuals 
and Consensus to present the imagined outcome at the poll as victory, and inviting the electorate to be in agreement with the party thus: Àwa yóo ségun (victory is near). The direct translation of Àwa yóò șégun is "We will win." Therefore, 'will', a promissory note, is presented before the electorate in order for them to vote wisely and not waste their vote elsewhere; rather, to cast it in favour of the APC.

\subsubsection{Socio-cultural Allusion}

The discourse of PCSs also engages the use of sociocultural allusion. Socio-cultural allusion essentially concerns reference to certain social issues and cultural realities in a given community in particular or society at large. Through PCSs, politicians often allude to socio-cultural issues which are often relevant and capable of convincing or bringing about a change of heart for the electorate. Consider the example below:

\begin{tabular}{|c|c|c|}
\hline \multirow{4}{*}{ Text 3} & $\begin{array}{l}\text { Ó fẹ ìtọjú nla } \\
\text { Ó fé àmóiútó }\end{array}$ & $\begin{array}{l}\text { A person who once } \\
\text { belonged to POWER camp } \\
\text { but has now }\end{array}$ \\
\hline & Eni tó ń șe power tẹlẹ̣ & metamorphosed to be a \\
\hline & Tó tún wá d'agbálẹ ọjà & sweeper at the market \\
\hline & Ó fẹ́ àmójútó & $\begin{array}{l}\text { square needs serious } \\
\text { (medical/spiritual) attention }\end{array}$ \\
\hline
\end{tabular}

Text 3 alludes to some socio-cultural concepts which cannot be easily understood by a non-Yoruba person. The concept of àmójútó (medical or spiritual attention) refers to someone who is an invalid, or more importantly, someone with psychosis, or who is exhibiting traces of lunacy. Text 3 alone is embedded with at least ten IDSs: Actor description, Disclaimers, Euphemism, Example/Illustration, Implication, Metaphor, Negative other-presentation, Polarisation, Presupposition, Dramatisation. Using the text as a deliberate attack on APC members who cross-carpeted from PDP, PDP showed their displeasure by negotiating between dropping the umbrella (the symbol of PDP) for the broom (the symbol of APC). The expression, Eni tó ń șe power tẹlè tó tún wá d'agbálè ojà, ó fẹ àmójútó (a person who once belonged to POWER camp but has now metamorphosed to be a sweeper at the market square needs serious medical/spiritual attention) alludes to socio-cultural orientation. With the IDSs, the text negatively describes APC disclaiming to save their face by hyperbolically metaphorising them as invalids. The euphemistic negative APC-presentation can really be fully understood by someone with shared cultural knowledge agbálè ojà (a sweeper at the market square). Culturally, when an individual is addressed as a sweeper at the market square, this is a pointer to the fact that the person is not mentally balance. Therefore, the socio-cultural reference to defame the character of such politicians by equating them to lunatics presupposes and indexes non-competence and imbalance.

\subsection{Propaganda}

This has to do with reference to ideas or statements, which may convey falsehood or exaggeration, and used with the intention of gaining support for PCs and possibly cast aspersion on POs. Propaganda, as a popular aspect of political discourse, concerns the manipulative power of language. In a bid for PCs to win their POs at polls, politicians and political parties often intentionally use language either to castigate their opponents or to advance their own cause. In essence, politicians get involved in opponent demonization, opponent criminalization and opponent condemnation in order to appear credible. On the other hand, propaganda is also used for self-advancement by hyping the achievements and capabilities of the campaigning political figure. Both forms of propaganda are represented in our data, as discussed.

\section{Text 4 Àyípadà dé sí Nigeria (4ce) It is a dawn of a new Àyípadà dé sí Nigeria era in Nigeria.}

Text 4 is an example of positive political propaganda, canvased by the APC in order to further enshrine their change mantra, especially in 2015. As much as this propagandistic language of change is the wish of every Nigerian, electorate are not easily swayed by it anymore based on past experiences. The expression, Ayípadà dé sí Nigeria (it is a dawn of a new era in Nigeria) deploys the IDSs of National Self-Glorification and Positive SelfPresentation strategy that implicate a glorified geographical location and country, Nigeria, where all things become new and governance becomes the expectation of an average citizen, and a country where each person will be able to feed. Unfortunately, the reality is contrary. The expression therefore becomes a propagandistic language used by PCs to appear credible and appealing to the electorate since the oration is different from what operates even after elections.

\section{Gbọ ohùn àwon Akálà tó ń korin Hear the sound of Gbọ́ ohùn àwọn Akálà tó ń kọrin Akálà's team \\ Text 5 Wọn ń korin tibọn tibọn Wọnn ń korin tọbe tọbe singing and Gbó ohùn àwọn Akálà tó ń korin guns and cutlass.}

Text 5 was used by the APC to attack Otunba Alao Akala (former Governor of Oyo State). The vilification was meant to discredit him and implicate him as a misfit for the government house. No doubt, it is a criminal offence to unlawfully go about with cutlasses (tọbe tọbe) and guns (tibọn tibọn) in a sane society. Different IDSs, including Actor Description, Consensus, Counterfactuals, Euphemism, Hyperbole, Implication, Irony and Negative other-presentation were deployed here to castigate Otunba Alao Akala (Akala). Whenever persons display or flaunt guns and cutlasses with reckless abandon, such persons can be associated with hooligans, criminals and those who need police and or legal interrogation. The propagandistic language strategy here uses Negative other-presentation to castigate and actor-describe Akala as a misfit for the position. The description also uses Counterfactuals to create the image of a "criminal governor" in the heart of the electorate. Since it is certain that a campaign group cannot be going about campaigning and brandishing 
cutlasses and guns, except if they do not want the peace-loving masses and electorate to attend the rally, the rhetoric of the PCSs, therefore, is not only hyperbolic, it is also ironical. Hence, the rhetor deploys Consensus to invite the electorate into agreement and solidarity, implicating and relegating Akala as morally unfit, in order for the electorate to embrace the other party and candidate.

\subsection{Indigenous Language Usage and Code Alternation}

Indigenous language usage has to do with the deployment of language that belongs to the immediate or native community of usage. On the other hand, code alternation has to do with a movement between one language and the other. Code-alternation - a sociolinguistic concept - subsumes both code-switching and code-mixing which are borne out of the influence that two or more languages in contact have on each other. It has to do with the use of different languages or dialects in the same conversation or sentence by a bilingual person [35], and in this context, we mean a switch or mix between English and Yoruba, as evidently deployed in our data. The use of code-alternation by politicians in PCSs is to promote communality, belonging and accommodation. Communality concerns the use of language to promote community oneness; belonging is to depict identification, where a politician identifies with the masses; and accommodation is meant to bring semi-literates into a discourse. Hence, the use of native language, especially in the southwestern part of Nigeria, where some do not understand and communicate in English, allows the PCs to have better access to the people. Meanwhile, for the semiliterate, when codes are alternated, they have better opportunity to become ratified into a discussion arena rather than being unratified or completely shut off. Text 6 is an example of outright use of indigenous language while text 7 is an example of code-alternation.

$\begin{array}{lll} & \text { Ilé ló lọ tàràrà } & \text { Home coming is his } \\ \text { Text } & \text { Ilé ló lọ tàràrà } & \text { lot. } \\ 6 & \text { Otuoke di’lé rẹ̀ o } & \text { Otuoke is his next } \\ & \text { Ilé ló lọ tàràrà } & \text { destination/abode. }\end{array}$

Text 6 was used at the APC presidential rally in all the six southwestern states in 2015. Sung, using one of the Nigerian major indigenous languages, Yoruba, it was meant to reach a wider Yoruba audience and possibly exclude non-Yoruba audience from the discourse. The song was used as an attack against the then sitting President Goodluck Ebele Jonathan (GEJ) who hailed from Otuoke in Bayelsa State, Nigeria. The implicature in the song is that GEJ will be voted out of Aso Rock and Abuja in 2015 and the APC of President Muhammadu Buhari (PMB) will take over. The expression Ilé ló lo tàràrà (Home coming is his lot), crafted using IDSs of Counterfactuals, Hyperbole, Metaphor and Implication, appeals to the sentiments of voters to also ensure that GEJ is voted out and PMB is voted in so that the prognosticated home coming can actually come to fruition.

\section{Bye bye to jágbajàgba \\ Bye bye to réderède \\ Ní İpínlè Òyọ́, \\ Bye bye to jágbajàgba \\ End has come to recklessness in Oyo State.}

Text 7 was used by the APC (then ACN) contestants, led by Senator Abiola Ajimobi (Ajimobi) in the 2011 governorship election in Oyo State as a strategy to bring an end to the Akala government. In an attempt to bridge the gap between the literate and the non-literate, there was the deployment of codealternation where the music changes from English (Bye bye to) to Yoruba (jágbajàgba, réderède). This strategy, therefore, brings about accommodation for the non-literates, tests that the $\mathrm{PC}$ is knowledgeable in the indigenous language and belongs to the community. Since Nigerians had criticised the PDP government under the leadership of Akala of recklessness to the detriment of the masses, the singer used the song to present APC and Ajimobi as the chosen candidate to terminate the suffering meted out to the people via the recklessness. APC/Ajimobi is represented as a liberator, destined to end the irresponsibility and unruliness in Oyo State. This representation is specifically meant to draw the masses to the party and the APC and its flag-bearer to depict the sense of cleansing and freedom from all sorts of problems and sufferings that Oyo State indigenes have been undergoing under the government of the PDP.

\subsection{Repetition}

Repetition concerns saying some things or same thing over and over. Repetition "of structures in the political texts is particularly significant because of its rhetorical effect" [10]. The essence of repetition is to emphasise and possibly make listeners remember easily. Repetitive rendition in music underscores easy committal of lines to heart. This is also a campaign strategy with which citizens easily spread the names of a political candidate beyond space and time.
Mo le moba
Mo tún gbà á padà
Mo le moba
Mo le moba
Mo tún gbà á padà
Ire gbogbo t'ộtà á gbà lộwọ́ mi

Text 8 Mo tún gbà á padà

Text 8 with the expression, Mo le moba, mo tún gbà á padà (I ran after and retrieved it), which was repeated thrice, has some peculiar features. In the first place, it creates a kind of suspense, where the listener is curious and left yearning to know what the PC ran after and retrieved. Besides, it also emphatically impresses in the mind of the addressee the untiring exploits of the PC. The fourth sentence finally spits the much desired Ire gbogbo t'ótà á gbà lówó mi (the mandate that the enemy stole from me). Meanwhile, the message itself was used by Akala during the 2015 and 2019 campaign rallies. Akala was the governor of Oyo State from 2007 to 2011. However, since Ajimobi rescued power from him in 2011, Akala's rhetoric is strategically positioned to incriminate Ajimobi as a rigger that 
rigged the 2011 election to have defeated Akala, as evident in gbà lówó mi (snatched my mandate) in Akala's rhetoric. In a bid to convince the electorate, text 8 deploys IDSs, including Comparison, Negative other-presentation, Dramatisation and Polarisation. Text 8 compares between Akala and Ajimobi, negatively presenting Ajimobi as the enemy and polarising them into ingroup - friend, and outgroup - enemy. The condemnation of Ajimobi as ótà (enemy) is a conceptual sentimental appeal and invitation to the electorate to derelict the Ajimobi camp and cling to the Akala camp.

\subsection{Reference to Collective Ownership}

Collective ownership is a term used to refer to what belongs to more than one person at a time. This is a strategy deployed in the PCSs to make listeners, in general, and electorate, in particular, have a sense of belonging, as exemplified in text 9 .

APC yìi ti'gbogbo wa ni,

Text 9 Kò mà gbọdọ bàjẹ

Torí kò'síbòmíràn tí a lè lọ

APC belongs to all.

It must not be destroyed because there is no other party like it.

In text 9, APC deploys two striking IDSs, including Norm expression and Number game, intended to convince the electorate that APC is the right path to follow. Sung at most of their campaign rallies, the song is deployed by the APC as a rallying strategy to throw the party at all and sundry, hoping they join hands with them to embrace the party. The expression, $A P C$ yil ti'gbogbo wa ni (This APC belongs to all of us), underscores the fact that the party is one that belongs to all Nigerians. The utilisation of gbogbo wa (all of us), which implies the subjective collective "we" and objective inclusive "us", implicates Norm expression and Number game argumentation rhetoric that all Nigerians need to have the sense of belonging and collective ownership in the APC vision. The next expression, kò mà gbodò bàjẹ (it must not be destroyed), and the last one, tori kòsíbòmíràn tí a lè lọ (because there is no other party like it), are sentiment-driven political rhetoric deliberately meted out to emotionally blackmail the electorate into voting the APC in order to have a sustained victory. The question is: can it truly be said to belong to all Nigerians?

\subsection{Figurative/Proverbial Expressions}

Figurative expressions are expressions deployed in rhetoric to convey additional layers of meaning in ways other than literal. On the other hand, proverbial expressions can be described as a type of conventional saying that is similar to proverbs and transmitted by oral tradition. Figurative and proverbial expressions are deployed in political rhetoric to arrest attention, arouse emotions and persuade readers or listeners [10] so as to generate an emotional reaction. No doubt, such expressions are deployed to enhance the comprehension and interpretation of the political discourses which are situated in the context of production, especially the socio-cultural context.

Text Eníbáwadìtẹ, kònír'ówójẹun All our

10 Ẹníbáwaditẹ̀, kònír'ówójẹun conspirators/saboteur

\section{İrókò tó gbàbọ̀dè gígé la ó $\quad \mathrm{s}$ are doomed to fail ge or suffer poverty.}

In text 10, there are at least two expressions at play: figurative (metaphor) and proverbial. The first part of the musical rhetoric says Eníbáwaditè, kònír'ówójẹun Eníbáwaditẹ, kònir'ówójẹun (All our saboteurs/conspirators are doomed to fail or suffer hunger), which is metaphorical. The expression metaphorises and equates an APC rebel or antagonist to a poverty-stricken person. What is the intent of such metaphorical expression? It is a politically-motivated move to arrest the attention of the electorate, arouse their emotions and maybe scare them, using the ideological discourse strategy of Counterfactuals, which possibly negates their initial thought on the likely outcome of voting the other party. Secondly, the electorate who see it as expletive are overtly conscious and scared about the power of words. Hence, the outright spat of financial insolvency will likely yield distancing from the opposition to the APC. Meanwhile, on the last line of the song is the expression, İrókò tó gbàbòdè, gígé la ó ge (An African teak tree that harbours evil must be fallen/destroyed). This is both a proverbial expression and metaphorical figurative expression which emphasizes the need to cut off or get rid of political saboteurs. This expression is more like a warning and it is intended to persuade the electorate against voting the opposition.

\subsection{Adaptation of Common Musical Tune}

The utilisation of musical tunes that resonates with the addressee and electorate in general is another discourse strategy deployed in PCSs. Music illuminates the mind, providing an interpretative language which helps the understanding of the people about the message contained in its background; it has become a tool in the campaigns for the adoption of innovations [36]. Using common musical tunes earns the song the much desired popularity and makes it easy to remember. Most of the tunes in the songs are either adapted from Yoruba hymn books, used mostly in orthodox churches, or adaptation from existing songs by popular Yoruba music artistes.

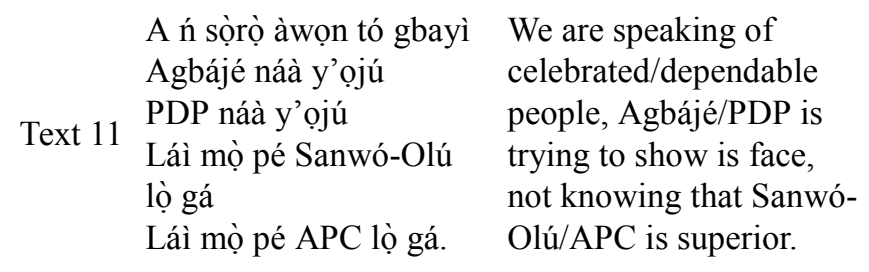

The background to the political jingle in text 11 is the 2019 gubernatorial election campaign in Lagos. However, the APC's rendition evinces to the electorate that, in matters of governance which would include, infrastructural development, economic buoyancy, political stability, good and acceptable policies, and so forth, both APC and SanwoOlu are better party and candidate who the people can trust since they are superior to their opponent. To convince the electorate, text 11 deploys IDSs, including Categorisation, 
Comparison and Negative other-presentation. While Comparison is used to compare between the two factions involved, categorisation is used to create an APC/PDP dichotomy on the one hand, Sanwo-Olu/Agbaje dichotomy on the other hand. Text 11 also withholds the word gbayi (dependable) from PDP in order to negatively represent PDP and Agbaje as not dependable. Therefore, in order to engrave the message in the heart of the electorate, the musician takes recourse to a popular tune that is easy to remember. In addition, text 9 was adapted from a popular musical tune by Sunday Adeniyi Adegeye, popularly known as King Sunny Ade (KSA). The original rendition by KSA was:

Nigeria yìi ti'gbogbo wa ni, Kò mà gbọdọ bàjẹ Torí kò'síbòmíràn tí a lè lọ, Àjò kò lè dà bíi 'lé E jé ka s'owọ́ pọ kà fìmọ sọ̀kan, Gbe k’èmi gbe.

\section{Which means}

Nigeria belongs to all. It must not be destroyed because there is no other place like home. Let's join hands and hearts together and lift Nigeria up.

The original version by KSA preaches the need for Nigerians to join hands together to promote the needed unity for development of the country. APC adopts both the musical tune and the message to entrench the need to collectively lift the party to the next level. Most Nigerians are familiar with the tune of the song, and the rendition of the adapted version becomes quite easy to remember.

\subsection{Rhythmicity (Rhyming Musical Rhythm)}

Rhythmicity concerns a state of being rhythmic or of responding to something rhythmically. Rhythm has to do with a regular repeated pattern of sounds or movements or a regular ordered recurrent alternation of strong and weak elements in the flow of sound and silence in speech which is often good to the ear. Such renditions are always easy to remember and easily get stuck to the heart of the listeners. The examples of such are found in almost all that we have used in this paper.

\section{Conclusion}

This paper set out to subject political campaign song discourse in southwestern Nigeria to discourse analysis, using data from the PCSs of 2011-2019 and applying relevant aspects of van Dijk's socio-cognitive model of critical discourse analysis, which assisted in uncovering the vital relationship existing between the political campaign songs and the Nigerian socio-cultural spatial setting that produced them. The analysed data revealed eight discursive strategies: allusion (historical, religious, socio-cultural), propaganda, indigenous/native language usage and code alternation, reference to collective ownership, figurative/proverbial expressions, adaptation of common musical tune, and rhythmicity. Twenty-two ideological discourse structures (Actor description, Authority,
Categorisation, Comparison, Consensus, Counterfactuals, Disclaimers, Euphemism, Evidentiality, Example/Illustration, Hyperbole, Implication, Irony, Metaphor, National SelfGlorification, Negative other-presentation, Norm expression, Number game, Polarisation, Presupposition and Dramatisation) were engaged to achieve the discursive strategies.

The eight discursive strategies evince our argument that Nigerian politicians and political contestants use lexically-dense discourses in their political campaign songs to open the door to the heart of the electorate, arrest attention, arouse emotions, persuade and, ultimately, request electorate to vote in their favour. Therefore, intended to bring people from different sociological background together and creating for them a collective experience [30] (Ramet, 1994), the political musical renditions possess "a greater unifying power than other forms of campaigning because it has the ability to transcend language, cultural and socioeconomic barriers" [22] (Peterson, 2018, p. 4). The discursive strategies embed in the music significantly impacts humans at both emotional and cognitive levels, transcending an array of possible barriers, and constituting the space where expression meets with art. The selected political campaign songs show that politicians continue to seek to appropriate popular music to communicate with constituents that they may assume to be hard to reach, such as non-literates, semiliterates, youth and ethnic minorities [32] (van Zoonen 2005).

Nigerian politicians have seen the potency of music which is "complexly structured, affectively significant, attentionally entraining, and immediately-yet indeterminatelymeaningful" [33] (Cross (2012, p. 24) for political communication with the electorate, in particular, and Nigerians in general. Hence, political campaign songs have been used and will continue to be in the electoral process to deliver messages about political parties, their candidates and manifestoes, and to attract potential voters in Nigeria, Africa and the world over. However, politicians will do well to avoid such musical and discourse formations capable of sparking political violence.

\section{References}

[1] Osisanwo, W. 2003. Introduction to discourse analysis and pragmatics. Lagos: Femolus - Fetop publishers.

[2] Halliday, M. A. K. 1978. Language as a social semiotic: the social interpretation of language and meaning. London; Edward Arnold.

[3] Adeyanju, D. 2002. Sociolinguistics: an introductory insight. In Sola Babatunde and Dele Adeyanju, eds. Language, meaning and society: papers in honour of E. E. Adegbija at 50. Ilorin: Haytee Press.

[4] Engholm, E. (1965). Education through English. Cambridge: Cambridge University Press.

[5] Osisanwo, A. 2016a. Vote for us, not for them: discursive strategies and ideological structures in the 2015 campaign SMS messages for the next faculty head. Ibadan Journal of Humanistic Studies. 26 (1): 135-157. (Nigeria). 
[6] Osisanwo, A. 2011a. Language and ideology in news magazines' representation of Nigeria's 2003 and 2007 general elections. PhD. Thesis: Department of English, University of Ibadan. xiv+243.

[7] Chilton, P. 2004. Analysing political discourse: theory and practice. London: Routledge.

[8] Ademilokun, M. \& Taiwo, R. 2013. Discursive strategies in newspaper campaign advertisements for Nigeria's 2011 elections. Discourse and Communication 7 (4): 435-455.

[9] Osisanwo, A. 2010. Language, style and meaning in political slogans. In Sola Babatunde, Akin Odebunmi, Akin Adetunji, Mahfouz Adedimeji, eds., Studies in slang and slogans. Germany: LINCOM EUROPA publishers. 275-288.

[10] Opeibi, B. O. 2009. Discourse, politics and the 1993 presidential election campaigns in Nigeria: a Re-Invention of June 12 Legacy. Lagos: Nouvelle Communications Limited.

[11] Akinwale, $\mathrm{T}$ and Adegoju, A. 2013. Aspiring vicechancellors' rhetoric and the challenges of building a twentyfirst century Nigerian university. JHEA/RESA. 10 (2): 25-46.

[12] Odebunmi, A. 2009. Politeness and relational work in print media political interviews in Nigeria. In Akin Odebunmi, Arua E. Arua and Sailal Arimi, eds., Language, gender and politics: a festschrift for Yisa Kehinde Yusuf. Lagos: Concept Publications, 339-356.

[13] Awonuga, C. O. 1988. Political rhetoric: Awolowo's use of language. ODU: A Journal of Western African Studies. 34. 28: 150-196.

[14] Ayeomoni, M. O. 2007. Lexical analysis of select political discourses of Nigeria's military Heads of State. Ph. D Thesis: Department of English, University of Ibadan.

[15] Alo, M. and Igwebuike, E. E. 2009. A stylistic analysis of Major Chukwuma Kaduna Nzeogwu's coup's speech. In Akin Odebunmi, Arua E. Arua and Sailal Arimi, eds., Language, gender and politics: a festschrift for Yisa Kehinde Yusuf. Lagos: Concept Publications, 327-338.

[16] Osisanwo, A. 2011b. A semiotic analysis of selected political posters in the development of politics in Nigeria. In Akin Alao, ed. Politics, Culture and Development in Nigeria: A Festschrift for Gabriel Olatunde Babawale. Lagos: Centre for Black Arts and African Civilization. 77-88.

[17] Osisanwo, A. 2012. Conversationalization of discourse in Tell and The News' representation of Nigerian general elections (NGE). Working Papers: Journal of English Studies, 5 (1), 166-185.

[18] Osisanwo, A. 2013. Discourse representation in news stories on Obasanjo's third-term plot in TELL and THE NEWS. Ibadan Journal of Humanistic Studies. 23.1: 115-141.

[19] Osisanwo, A. 2016b. Role allocation in the media representation of participants in selected electoral discourses in Nigeria. Athens Journal of Mass Media and Communications. 2 (3): 183-204.

[20] Oyeleye, L and Osisanwo, A. 2013a. Expression of ideologies in the media representation of the 2003 and 2007 general elections in Nigeria. Discourse and Society. 24.6: 763-773.
[21] Oyeleye, L. and Osisanwo, A. 2013b. Lexicalisation in media representation of the 2003 and 2007 general elections in Nigeria. World Journal of English Language, Vol. 3.2: 1-9.

[22] Peterson, L. E. 2018. A rhetorical analysis of campaign songs in modern elections (Unpublished master's thesis). Brigham Young University, Provo, Utah. Retrieved from https://scholarsarchive.byu.edu/etd/6718.

[23] Kachii, V. 2018. Politically motivated campaign songs and voting behaviour: reflections on tiv campaign songs in the 2015 elections in Benue State, Nigeria. Africology: The Journal of Pan African Studies, 12 (6), 202-214.

[24] Obono, K. 2017. Music and political communication in post independence southwest Nigeria. In Adebola B. Ekanola \& Dele Adeyanju, eds., Topics in Humanistic Studies. Ibadan: UI Faculty of Arts. 140-160.

[25] Aririguzoh, S. 2019: Music, political messaging, and Nigeria's 2015 presidential election. In Uche T. Onyebadi, ed., Music and Messaging in the African Political Arena. Texas: IGI Global. 261-281.

[26] Titus, O. S. \& Bello, O. A. 2012. Musical forms in songs for political mobilisation during 2011 general elections in Nigeria. International Journal of Humanities and Social Science, 2 (13), 166-173.

[27] Allen, L. (2004). Music and politics in Africa. Social Dynamics, 30 (2), 1-19. doi: 10.1080/02533950408628682.

[28] Gonzalaz, A. and Makay, J. 1983. Rhetorical ascription and the Gospel according to Dylan. Quarterly Journal of Speech, $69(1), 1-14$.

[29] Turino, T. 2008. Music as social life: The politics of participation. Chicago: University of Chicago Press.

[30] Ramet, S. P. 1994. Rocking the state: Rock music and politics in Eastern Europe and Russia.

[31] Sellnow, D. and Sellnow T. 2001. "The 'Illusion of Life' rhetorical perspective: An integrated approach to the study of music as communication. Critical Studies in Mass Communication, 18 (4), 395-415.

[32] van Zoonen, L. 2005. Entertaining the citizen: When politics and popular culture converge. Oxford: Rowman \& Littlefield.

[33] Cross, I. (2012). music and biocultural evolution. in the cultural study of music: a critical introduction (2nd ed.). Routledge.

[34] van Dijk, T. 2006. Politics, ideology and discourse. In Brown K., ed., The Encyclopedia Of Language and Linguistics. Vol. 9: 728-740. Oxford: Pergamon Press.

[35] Cárdenas-Claros, M. S. 2009. Code switching and code mixing in internet chatting: between 'yes', 'ya' and 'si' case study. The Jaltcall journal 5.3: 67-78.

[36] Ochonogor, C. I. 2005. The mass media as agents of development and social change in Africa. Abraka Humanities Review 1 (1): 123-137. 